\title{
The isotherm slope. A criterion for studying the adsorption mechanism of benzotriazole on copper in sulphuric $\operatorname{acid}^{(\cdot)}$
}

\author{
D.M. Bastidas*, P.P. Gómez** and E. Cano**
}

\begin{abstract}
The adsorption of benzotriazole (BTA) on copper surfaces in $0.001,0.005$ and $0.01 \mathrm{M}$ concentrations of sulphuric acid was investigated using gravimetric measurements. BTA was tested in concentrations from $1 \times 10^{-5}$ to $1 \times 10^{-1} \mathrm{M}$ at temperatures from 298 to $328 \mathrm{~K}$. The adsorption mechanism is discussed in terms of applicability of the conventional Frumkin, Bockris-Swinkels and Kastening-Holleck isotherms, among others. The best fit was obtained using the Frumkin isotherm model. The projected molecular area of BTA was calculated to elucidate inhibitor orientation in the adsorption process.
\end{abstract}

Keywords Copper. Sulphuric acid. Benzotriazole. Adsorption isotherm. Objective function. Projected molecular area

\section{Pendiente de la isoterma. Un criterio para estudiar el mecanismo de adsorción del benzotriazol sobre el cobre en ácido sulfúrico}

\begin{abstract}
Resumen
En el presente trabajo se estudia la adsorción del benzotriazol (BTA) sobre el cobre en solución de ácido sulfúrico con concentraciones de 0,001, 0,005 y 0,01 M utilizando medidas gravimétricas. La concentración de BTA ensayada varió de $1 \times 10^{-5} \mathrm{M}$ a $1 \times 10^{-1} \mathrm{M}$ y la temperatura de $298 \mathrm{~K}$ a $328 \mathrm{~K}$. El mecanismo de adsorción se analiza en términos de la aplicabilidad de las isotermas convencionales de Frumkin, Bockris-Swinkels y KasteningHolleck, entre otras. La mejor descripción de los resultados se obtuvo utilizando la isoterma de Frumkin. Para analizar la orientación del BTA en el proceso de adsorción sobre el cobre, se calculó la superficie de la molécula de BTA.
\end{abstract}

Palabras clave Cobre. Ácido sulfúrico. Benzotriazol. Isoterma de adsorción. Función objetivo. Área molecular proyectada.

\section{INTRODUCTION}

Copper is widely used in many applications such as heat exchangers, condensers, heating and air conditioning systems, electricity, electronic circuitry and ornamental parts. Pickling in dilute hydrochloric and sulphuric acids is the most common method for removing oxides formed on the surface of copper-based materials during mill processing and fabrication operations ${ }^{[1-4]}$.

Benzotriazole (BTA) is an effective corrosion inhibitor for copper in acid solutions ${ }^{[5-7]}$. Basically two mechanisms have been proposed in the literature: the adsorption of single BTA molecules on the copper surface and the formation of a protective polymeric film involving the complex ions $\mathrm{Cu}(\mathrm{I})$ and $\left[(\mathrm{Cu})^{+}(\mathrm{BTA})^{-}\right]_{\mathrm{n}}{ }^{[8-10]}$. Nevertheless, despite the widespread use of BTA no consensus has been reached on its mechanism. On the other hand, there is also a lack of agreement regarding the orientation of BTA on the copper surface. Some authors propose a flat orientation on the surface and bonding through the lone-pair nitrogen orbitals, with lone nitrogen atoms bonded to two copper atoms ${ }^{[4,11}$ y 12]. The loss of the imino hydrogen converts each BTA molecule into a (BTA $^{-}$ion, with a conjugated $\pi$ structure delocalised over the three nitrogen atoms ${ }^{[13}$ y 14$]$. It

(•) Trabajo recibido el día 20 de septiembre de 2004 y aceptdo en su forma final el día 14 de enero de 2005.

$(*)$ School of Chemistry, University of St. Andrews, St. Andrews, Fife KY16 9ST, Scotland, United Kingdom.

(**) CENIM-National Centre for Metallurgical Research, CSIC, Avda. Gregorio del Amo 8, Tel.: +34 915538900 ; Fax: +34 915347425 ; E-mail address: ecano@cenim.csic.es (E. Cano).E-28040 Madrid, Spain. 
has also been claimed that BTA does not lie flat on the surface, but that the nitrogen lone-pair orbitals bond to the copper surface atoms ${ }^{[15]}$. An angle orientation not far from the horizontal and not vertically on the copper surface has also been proposed $^{[16]}$.

The aim of this paper is to study the inhibition mechanism of BTA on copper electrode surfaces in a sulphuric acid solution, based on analysis of the properties of the thermodynamic isotherms including the interaction term $(f)$ parameter (Temkin, Frumkin, Hill-de Boer and Parsons equations), the configurational term $(\chi)$ parameter (Flory-Huggins, Dhar-Flory-Huggins and BockrisSwinkels equations), and both $f$ and $\chi$ parameters (Damaskin-Parsons and Kastening-Holleck equations). The shape, trend of the slopes along the curve, and the existence of inflection points were analysed as the characteristics that differentiate one adsorption equation from another. Special attention is paid to the objective function and the projected molecular area of the BTA molecule.

\section{EXPERIMENTAL}

The commercial copper used had the following chemical composition (by weight \%): $0.019 \mathrm{P}$, $<0.001 \mathrm{Fe},<0.001 \mathrm{As},<0.001 \mathrm{Mn},<0.002 \mathrm{Sb}$, $<0.001 \mathrm{Al}, 0.009 \mathrm{Sn}, 0.003 \mathrm{Ni}, 0.015 \mathrm{~Pb},<0.005$ $\mathrm{Ag},<0.001 \mathrm{Bi},<0.001 \mathrm{~S},<0.005 \mathrm{C}$, the balance being $\mathrm{Cu}$. The copper was phosphorus-reduced and had a low residual phosphorus content, Type C12000, ASTM B-224 standard ${ }^{[17]}$.

The specimens, $5 \mathrm{~cm} \times 5 \mathrm{~cm}$, were mechanically cut from a sheet $1.0 \mathrm{~mm}$ thick. The calculated exposed specimen surface area was $52 \mathrm{~cm}^{2}$. The specimens were dry hand-polished with emery paper down to grade 600 , degreased with acetone, rubbed with cotton wool soaked in ethanol, dried at room temperature, weighed to determine initial mass, and tested immediately.

Three sulphuric acid concentrations and $\mathrm{pH}$ values were tested: $0.001(\mathrm{pH} 3.0), 0.005(\mathrm{pH} 2.3)$ and $0.01 \mathrm{M}(\mathrm{pH} \mathrm{2.0)}$.

Twelve BTA $\left(\mathrm{C}_{6} \mathrm{H}_{4} \mathrm{~N}_{3} \mathrm{H}\right)$ concentrations were tested: $0.01,0.05,0.1,0.5,1,2,3,4,5,10,50$ and $100 \times 10^{-3}$ M. Commercial BTA and $\mathrm{H}_{2} \mathrm{SO}_{4}$ were used (Merck analytical grade chemicals).

$500 \mathrm{~mL}$ volume of the $\mathrm{H}_{2} \mathrm{SO}_{4}$ acid solution were tested in a glass vessel in the presence and absence of inhibitor. The temperature was maintained at $298,308,318$ and $328 \mathrm{~K}$ during the experiments by immersing the glass vessel in a thermostatically- controlled water bath. At the end of the experiments, each of $3 \mathrm{~h}$ duration, specimen mass loss was determined after removal of the corrosion products using a $10 \% \mathrm{H}_{2} \mathrm{SO}_{4}$ aqueous solution for 3 min at room temperature, ASTM G-1 standard $^{[18]}$. An electronic analytical balance with a precision of $\pm 0.1 \times 10^{-3} \mathrm{~g}$ was used. All the experiments were performed in triplicate in a single cell, i.e. the gravimetric corrosion rate is listed as the average value of three specimens studied under identical experimental conditions. The reproducibility of the experimental gravimetric results was higher than $95 \%$.

\section{RESULTS AND DISCUSSION}

Figure 1 shows the corrosion rate, $\mathrm{mg} / \mathrm{m}^{2}$ day, versus temperature for copper immersed in a $\mathrm{H}_{2} \mathrm{SO}_{4}$ acid solution in the absence of inhibitor. It can be observed that copper corrosion increases as the sulphuric acid concentration is raised from 0.001 to $0.01 \mathrm{M}$ and as the temperature passes from 298 to $328 \mathrm{~K}$.

The comparison of experimental adsorption data $\left(\theta_{\text {exp }}\right.$ and $\left.c_{\text {exp }}\right)$ and data predicted by a theoretical adsorption equation $\left(\theta_{\text {cal }}\right.$ and $\left.c_{c a l}\right)$ is frequently the criterion used to assess the validity of a theoretical expression to describe the adsorption equilibrium; where $\theta$ is the degree of coverage of the copper surface by adsorbed BTA

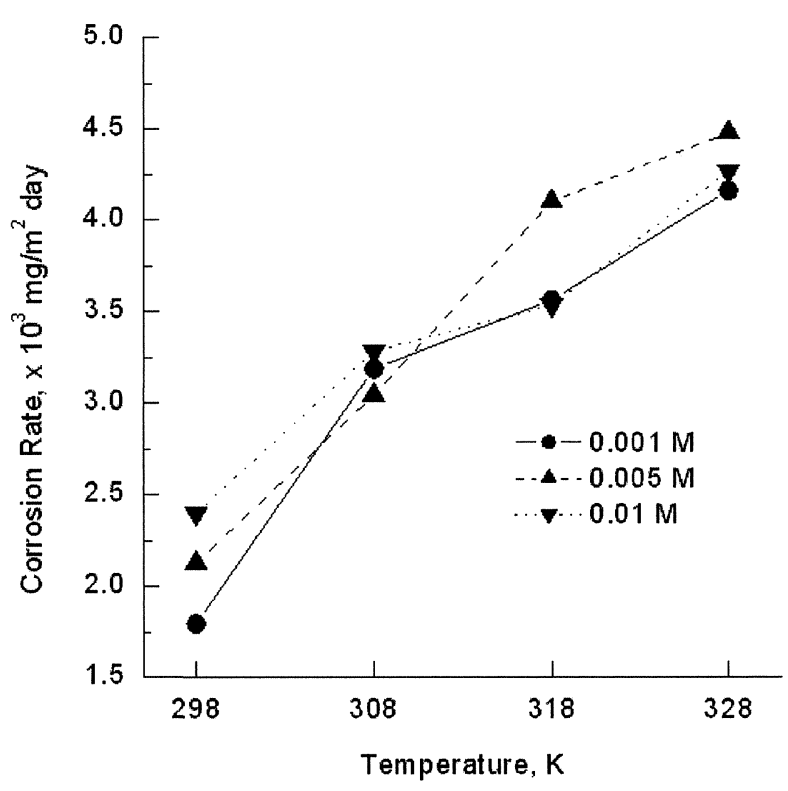

Figure 1. Copper corrosion rate, $\mathrm{mg} / \mathrm{m}^{2}$ day, versus temperature in $\mathrm{H}_{2} \mathrm{SO}_{4}$ acid solution.

Figura 1. Velocidad de corrosión del cobre, $\mathrm{mg} / \mathrm{m}^{2}$ día, frente a la temperatura en solución de ácido $\mathrm{H}_{2} \mathrm{SO}_{4}$. 
inhibitor and $c$ is the concentration of the BTA inhibitor. The $\theta$ value is obtained using the expression $^{[19]}$ :

$$
\theta=\frac{\mathrm{CR}_{\mathrm{abs}}-\mathrm{CR}_{\mathrm{pre}}}{\mathrm{CR}_{\mathrm{abs}}}
$$

where $C R_{a b s}$ and $C R_{\text {pre }}$ are the copper corrosion rates in the absence and presence of BTA, respectively. Equation (1) is valid on the assumption that: (i) the adsorption sites on the copper surface are homogeneous, (ii) a mono-layer inhibitor adsorption is formed, and (iii) corrosion is uniform and no localised attack takes place. The $c_{c a l}$ value is obtained by evaluation of the theoretical isotherm for a value of $\theta_{\text {exp }}$ and given the values of $k, f$ and/or $\chi$ parameters of the utilised isotherm (see Table $\mathrm{I})^{[20-30]} ; k$ is the equilibrium constant of the adsorption reaction:

$\mathrm{Cu}+\mathrm{BTA} \Leftrightarrow \mathrm{Cu}(\mathrm{BTA})_{\mathrm{ads}} \Leftrightarrow \mathrm{Cu}^{\mathrm{n}+}+\mathrm{ne}^{-}+\mathrm{BTA}$

given $\mathrm{k}=\left(\frac{1}{55.5}\right)\left[\exp \left(-\frac{\Delta \mathrm{G}_{\text {ads }}^{0}}{\mathrm{RT}}\right)\right] ; \mathrm{Cu}(\mathrm{BTA})_{\text {ads }}$ is a reaction intermediate. The value 55.5 is the water concentration in the solution in $\mathrm{mol} / \mathrm{L} ; \mathrm{R}$ is the gas constant $(8.314 \mathrm{~J} / \mathrm{Kmol}) ; T$ is the absolute temperature; $\Delta G_{\text {ads }}^{0}$ is the adsorption energy; $f$ is the interaction term parameter $(f>0$ lateral attraction interactions between adsorbed BTA molecules, and $\mathrm{f}<0$ lateral repulsion interactions between adsorbed BTA molecules); and $\chi$ the size ratio term (molecular) parameter is the number of water molecules displaced from the adsorbed layer upon the adsorption of one BTA molecule:

$$
\mathrm{BTA}_{\text {aqu }}+\chi \mathrm{H}_{2} \mathrm{O}_{\text {ads }} \Leftrightarrow \mathrm{BTA}_{\text {ads }}+\chi \mathrm{H}_{2} \mathrm{O}_{\text {aqu }}
$$

where $B T A_{a q u}$ is the inhibitor in the aqueous phase and $\chi \mathrm{H}_{2} \mathrm{O}_{a d s}$ is the number of water molecules adsorbed on the copper surface, $\chi$ is assumed to be independent of the coverage or charge on the electrode.

The best fit for a given theoretical isotherm is obtained when there is minimal difference between the experimental and calculated values. The expression used to optimise this difference is the objective function $(F)$ :

$$
\mathrm{F}=\sum_{\mathrm{i}=1}^{\mathrm{p}} \mathrm{w}_{\mathrm{i}}\left[\mathrm{c}_{\exp _{\mathrm{i}}}-\mathrm{c}_{\mathrm{cal}_{\mathrm{i}}}(\mathrm{k}, \mathrm{f}, \chi)\right]^{2}
$$

where the $i$ subscript represents one value in a set of $p$ concentrations of the BTA inhibitor $(1 \leq \mathrm{i} \leq \mathrm{p})$, and $w_{i}$ denotes the weight associated with the $i$-th experimental value. Ideally, $w_{i}$ should be the inverse variance of the individual measurements ${ }^{[31]}$. The next step is to choose the adequate $k, f$ and/or $\chi$ parameters to ensure that Eq. (4) has the minimum value.

All the isotherms in Table I are of the form:

$$
\mathrm{kc}=\mathrm{g}(\theta, \chi) \exp (-\mathrm{f} \theta)
$$

where $g(\theta, \chi)$ is the configurational term parameter (as pointed out above) that depends essentially on the physical model and assumptions underlying the derivation of the isotherm.

By considering Eq. (5), then Eq. (4) can be written as:

$\mathrm{F}(\mathrm{f}, \mathrm{k})=\sum_{\mathrm{i}=1}^{\mathrm{p}} \mathrm{w}_{\mathrm{i}}\left[\mathrm{c}_{\exp _{\mathrm{i}}}-\left(\frac{1}{\mathrm{k}}\right) \mathrm{g}\left(\theta_{\exp _{\mathrm{i}}} \chi\right) \exp \left(-\mathrm{f} \theta_{\exp _{\mathrm{i}}}\right)\right]^{2}$

Integer values for $\chi$, for instance ranging from 1 to 5 , were considered in this study.

Fitting has been carried out using the Levenberg-Marquardt (LM) algorithm to minimise $F$. The LM algorithm is robust, converges in many situations, is fast in computing time, and is a compromise between the Gauss-Newton method and the steepest descent method ${ }^{[32]}$.

The minimum value reached by the unweighted $F$ for copper in $0.001 \mathrm{M} \mathrm{H}_{2} \mathrm{SO}_{4}$ acid was 0.007 using the Frumkin equation; 0.088 to 1365118 for $\chi$ from 2 to 5 using the Damasking-Parsons equation; and 0.075 to 94055 for $\chi$ from 2 to 5 using the Kastening-Holleck equation, which means a poor fit for the latter two equations.

In order to study the adsorption of BTA on copper electrode surfaces, the properties of the isotherm equations from Table I: the existence of inflection points, the shape, and the trend of slopes along the curve were analysed as the characteristics that differentiate one adsorption equation from another.

The Langmuir slope, $\ln (10)(1-\theta) \theta$ (see Table I), shows that, for a given value of $\theta$, the slope takes a constant value, regardless of the value of $k$. The term $(1-\theta) \theta$ is a parabolic function with a maximum at $\theta=0.50$. Thus, the criterion for identifying Langmurian behaviour in a $\theta$ versus $\log (\mathrm{c})$ plot lies in the characteristic slopes of the curves. 
Table I. Adsorption isotherms used ${ }^{[20-30]}$

Tabla I. Isotermas de adsorción utilizadas ${ }^{[20-30]}$

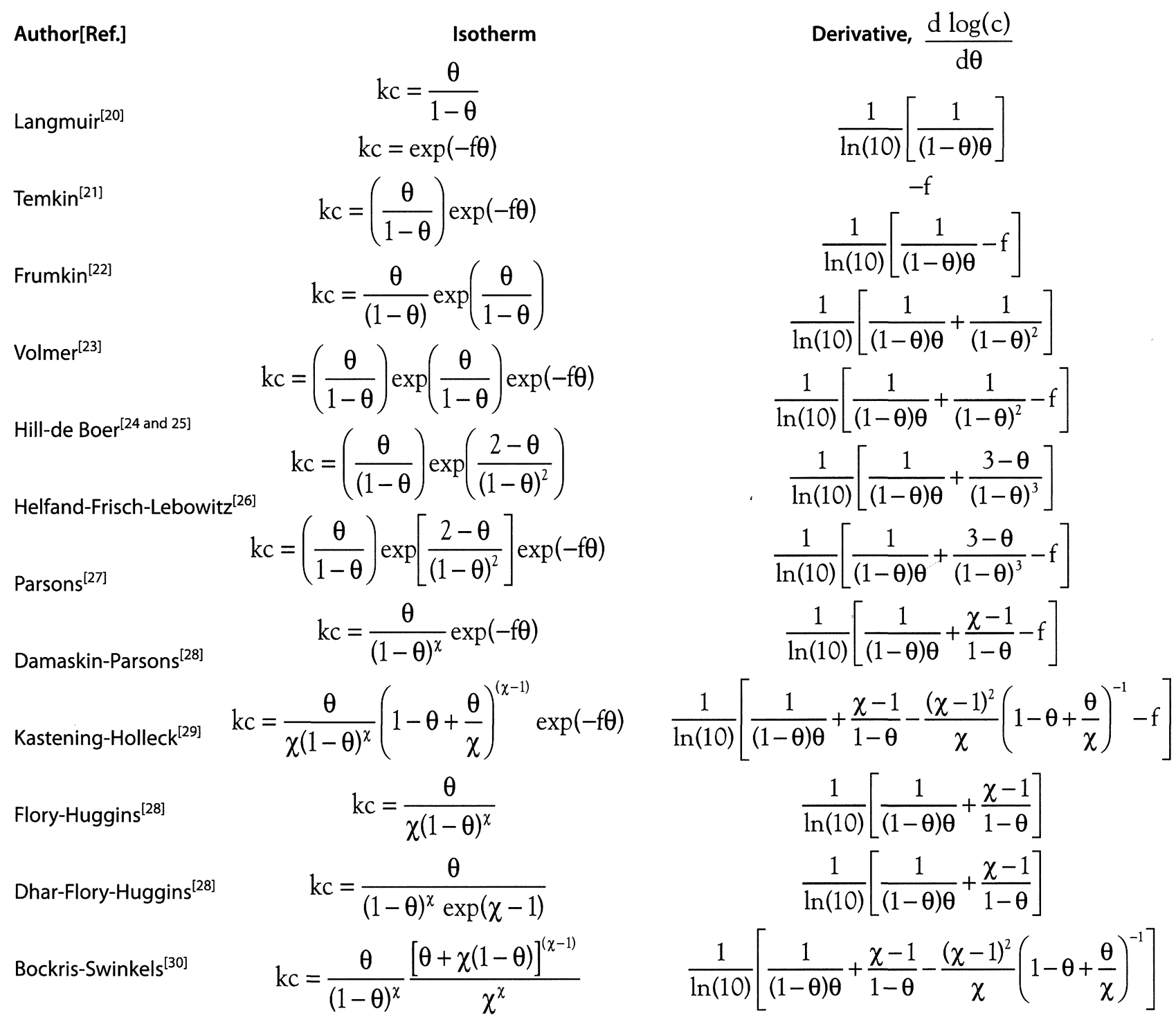

Figure 2 shows the slope of the Frumkin equation, $\frac{\mathrm{d} \log (\mathrm{c})}{\mathrm{d} \theta}=\frac{1}{\ln (10)}\left\lfloor\frac{1}{(1-\theta) \theta}-\mathrm{f}\right\rfloor$, as a function of $\theta$ for copper immersed in $0.001,0.005$ and $0.01 \mathrm{M}$ $\mathrm{H}_{2} \mathrm{SO}_{4}$ acid solution in the presence of BTA compound at 298-328 $\mathrm{K}$ temperatures. A cubic spline polynomial algorithm ${ }^{[33]}$ :

$$
\mathrm{A}[\log (\mathrm{c})]^{3}+\mathrm{B}[\log (\mathrm{c})]^{2}+\mathrm{C}[\log (\mathrm{c})]+\mathrm{D}
$$

where $A, B, C$ and $D$ are constants, was used to interpolate the adsorption data in the unmeasured BTA concentration domain between each pair of experimental data and to obtain the derivative $\frac{\mathrm{d} \log (\mathrm{c})}{\mathrm{d} \theta}$ for a continuous function.

The case where lateral attractive interactions between BTA molecules arise $(f>0)$ can be directly identified by observing the slope at intermediate coverage values. The slope of the Frumkin equation is steeper than that of the Langmuir equation, and the deviation is due to a positive $f$ value. For lateral repulsive interactions $(f<0)$ the slope of the Frumkin equation is less steep than that of the Langmuir equation. For the case where $\mathrm{f}=0$, the slope of the Frumkin equation is simplified to the slope of the Langmuir equation (see Table I). 
This means that, compared with the Langmuir equation, in the Frumkin equation the slope is modified by a constant value $f$. This effect is shown graphically in the theoretical inset of figure 2, where the slope, $\frac{\mathrm{d} \log (\mathrm{c})}{\mathrm{d} \theta}$, of the Frumkin equation is plotted as a function of $\theta$.

Figure 2 inset also shows that the Langmuir equation $(f=0)$ exhibits a minimum slope for intermediate coverage. At high or low coverage the slope values are determined by the term $\frac{1}{(1-\theta) \theta}$, which dominates whenever $\frac{1}{(1-\theta) \theta}>>f$.

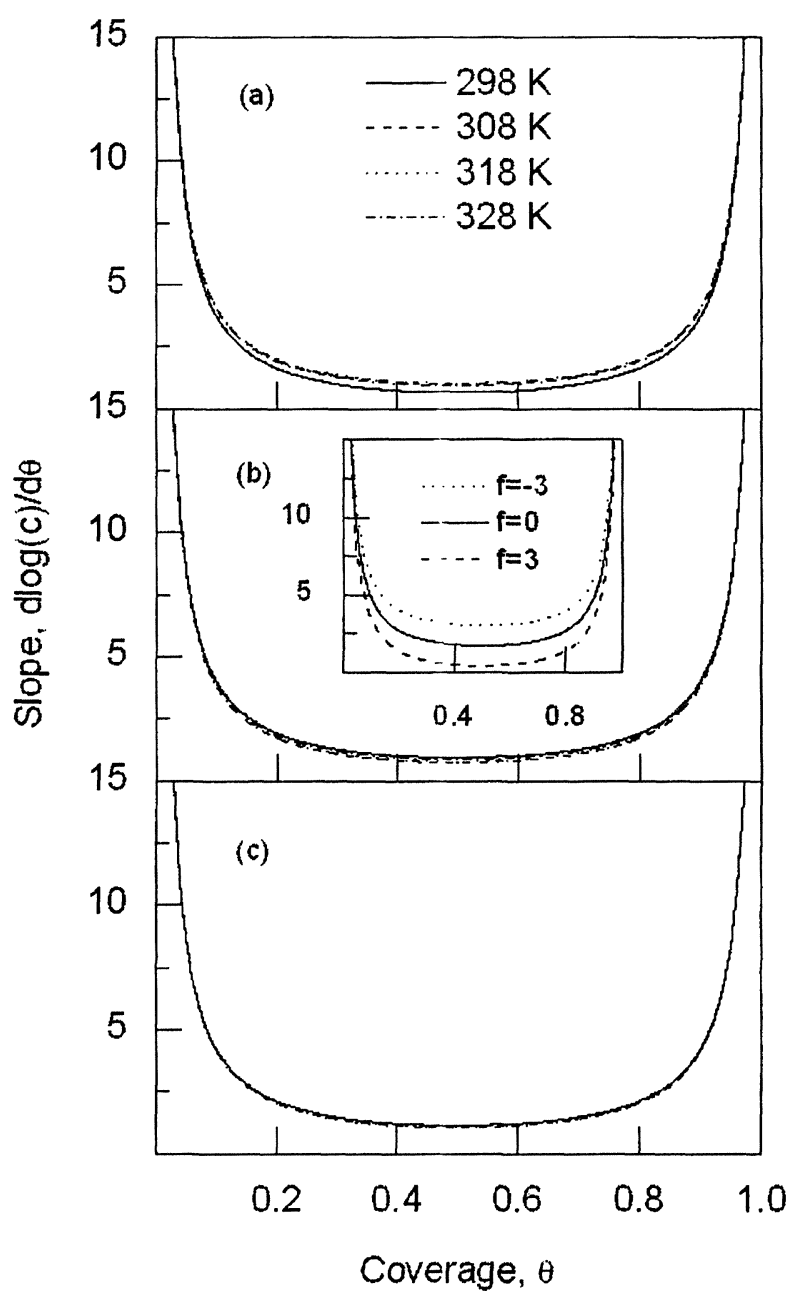

Figure 2. Slope versus coverage for copper in (a) 0.001 , (b) 0.005 , and (c) $0.01 \mathrm{M} \mathrm{H}_{2} \mathrm{SO}_{4}$ acid solution at 298, 308, 318 , and $328 \mathrm{~K}$ in the presence of BTA and for different values of $f$ (inset) using the Frumkin equation.

Figura 2. Pendiente frente a recubrimiento del cobre en solución de ácido $\mathrm{H}_{2} \mathrm{SO}_{4}$ (a) 0,001, (b) 0,005 y (c) 0,01 M a $298,308,318$ y $328 K$ en presencia de BTA y para diferentes valores de $f$ (ver diagrama pequeño) usando la ecuación de Frumkin.
Thus, $f$ is only able to modify the slope at intermediate coverage values (when $\frac{1}{(1-\theta) \theta} \sim f$ ) by shifting the Langmuir slope by a constant value of $f$. This shift can be positive (rising) for $\mathrm{f}<0$ or negative (falling) for $f>0$ (see Fig. 2 inset). This property is not exclusive to the Frumkin equation, and can be extended to any adsorption isotherms which include the $\exp (-f \theta)$ term, e.g. Temkin, Hillde Boer, Parsons, Damaskin-Parsons and Kastening-Holleck equations (see Table I).

The two-parameters ( $k$ and $f$ ) in the Hill-de Boer and Parsons equations are similar to the Frumkin equation. They produce $S$ curves with distinctive inflection points $\left(\theta_{i p}\right)$ at 0.33 for Hill-de Boer and at 0.21 for Parsons equations (see Fig. $3(\mathrm{a})$ ). This feature can be appreciated from their derivatives (see Table I). Figure 3(b) shows the theoretical variation of $\frac{d \log (c)}{d \theta}$ as a function of $\theta$ using the Frumkin, Hill-de Boer, and Parsons equations. The minima correspond to the $q_{i p}$ of the slope (in a $\theta$ versus BTA concentration plot), which is characteristic of each equation and independent of the $k$ and $f$ parameters. Finally, the Hill-de Boer and Parsons equations are depressed curves, and the slopes of the isotherms are sensitive to $f$ changes for $\theta \sim \theta_{\text {ip }}$. For the case where $f=0$, the slope of the Hill-de Boer and Parsons equations is simplified to the slope of the Volmer and Helfand-Frisch-Lebowitz equations, respectively (see Table I).

Figure 4 shows $\theta$ versus BTA concentration for copper immersed in $0.001 \mathrm{M} \mathrm{H}_{2} \mathrm{SO}_{4}$ acid at $298 \mathrm{~K}$ using the Damaskin-Parsons (Fig. 4(a)) and Kastening-Holleck (Fig. 4(b)) equations, respectively. As can be observed, a poor fit was obtained between the experimental and simulated data except for $\chi=1$, in which the DamaskinParsons and Kastening-Holleck equations coincide with the Frumkin equation (see Table I).

The derivative of the Damaskin-Parsons equation is identical to the Frumkin slope, apart from the term: $\frac{\chi-1}{1-\theta}$ (see Table I). Figure 5 shows that the contribution of this term increases as the value of $\theta$ rises and is responsible for the overall depression of the adsorption equation curve. The derivative of the Kastening-Holleck equation is identical to the Damaskin-Parsons slope, apart from the term: $-\frac{(\chi-1)^{2}}{\chi}\left(1-\theta+\frac{\theta}{\chi}\right)^{-1}$ (see Table I). 


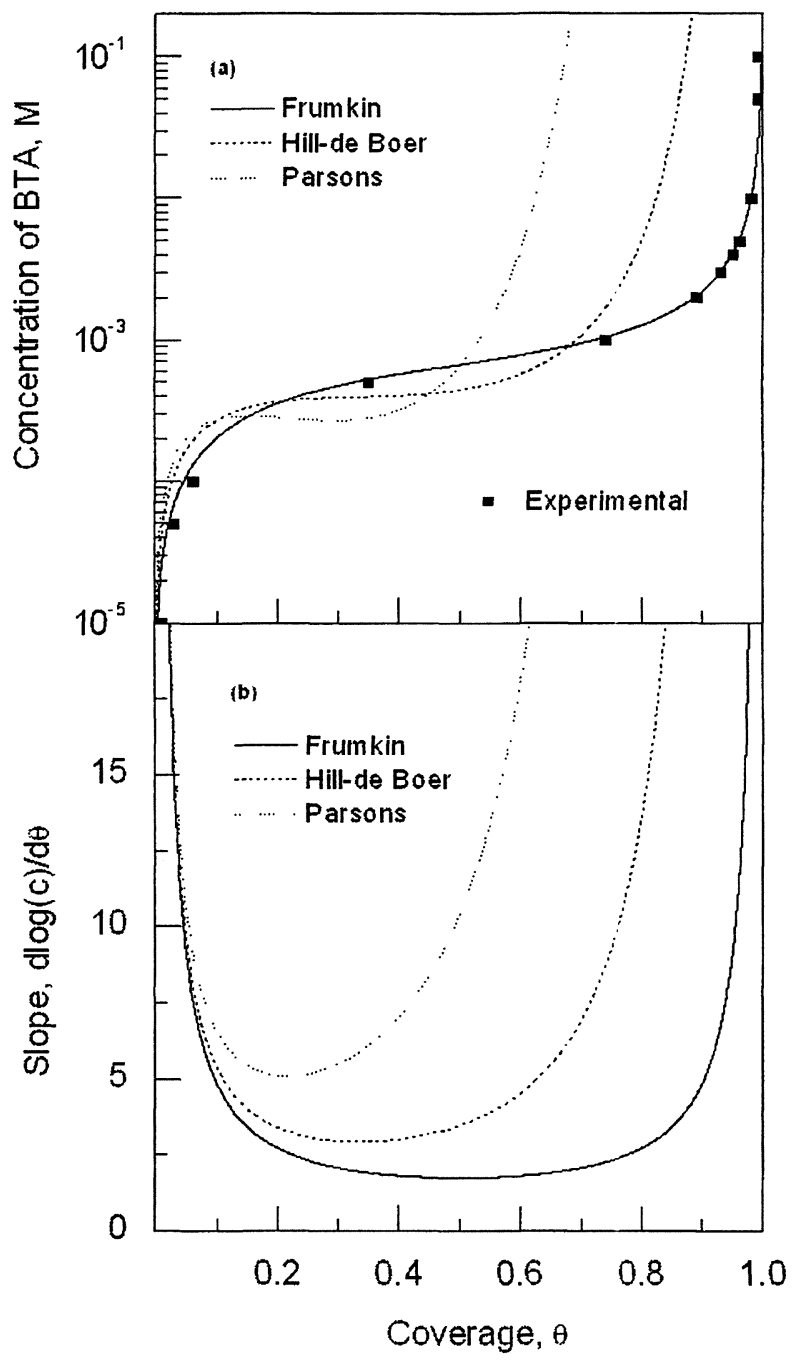

Figure 3. Copper in $0.001 \mathrm{M} \mathrm{H}_{2} \mathrm{SO}_{4}$ acid solution in the presence of BTA at $298 \mathrm{~K}$. (a) BTA concentration versus coverage using the Frumkin equation $(f=2.50$ and $k=430.795)$, the Hill-de Boer equation ( $f=6.46$ and $k=242.80)$, and the Parsons equation $(f=12.46$ and $k=1228.05$ ); (b) slope versus coverage theoretical behaviour for $\mathrm{f}=0$.

Figura 3. Cobre en ácido $\mathrm{H}_{2} \mathrm{SO}_{4} 0,001 \mathrm{M}$ en presencia de BTA a $298 \mathrm{~K}$. (a) Concentración de BTA frente a recubrimiento utilizando la ecuación de Frumkin ( $f=2,50$ y $k=430,795)$, la ecuación de Hill-de Boer $(f=6,46$ y $k=242,80)$, y la ecuación de Parsons $(f=12,46$ y $k=1228.05$ ); (b) comportamiento teórico de la pendiente frente al recubrimiento para $f=0$.

The latter term is the least important and affects the low coverage region. The minimum of the slope values in figure 5 serves as a criterion for distinguishing between species that adsorb according to the $\chi$ parameter and those that adsorb according to the $f$ parameter, Langmuir and Frumkin equations, which present a constant $\theta_{i p}$ at $\sim 0.50$. The derivatives of the Flory-Huggins and Dhar-Flory-Huggins equations are identical to the

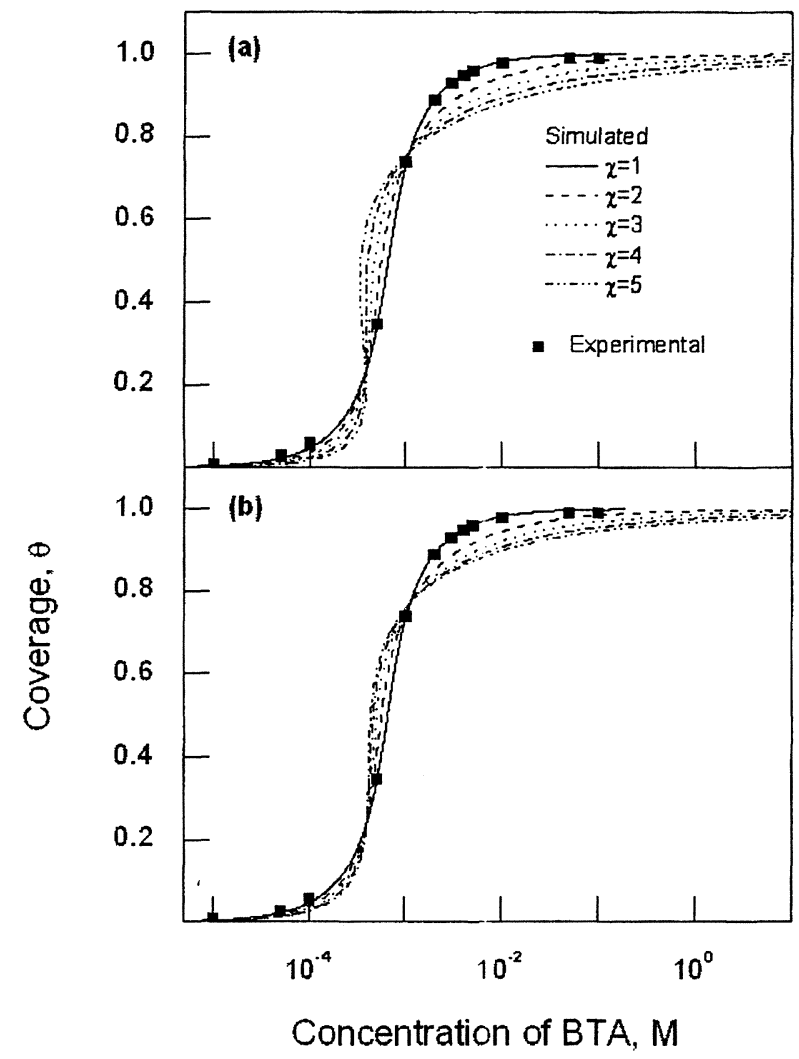

Figure 4. Coverage versus BTA concentration for copper in $0.001 \mathrm{M} \mathrm{H}_{2} \mathrm{SO}_{4}$ acid solution at $298 \mathrm{~K}$ and for different values of $\chi$, using: a) the Damaskin-Parsons equation: $\chi=1$ $(f=2.50, k=430.795), \quad \chi=2 \quad(f=4.71, k=336.09), \quad \chi=3$ $(f=6.92, k=262.21), \chi=4 \quad(f=9.13, k=204.56)$, and $\chi=5$ ( $f=11.34, k=159.59) ; b$ ) the Kastening-Holleck equation: $\chi=1 \quad(f=2.50, k=430.795), \chi=2(f=4.05, k=172.65), \chi=3$ $(f=4.93, k=98.30), \quad \chi=4(f=5.51, k=65.74)$, and $\chi=5$ ( $f=5.93, k=48.21$ ).

Figura 4. Recubrimiento frente a concentración de BTA del cobre en ácido $\mathrm{H}_{2} \mathrm{SO}_{4}$ 0,001 M a $298 \mathrm{~K}$ y para diferentes valores de $\chi$, utilizando: a) la ecuación de DamaskinParsons: $\quad \chi=1 \quad(f=2,50, \quad k=430,795), \quad \chi=2 \quad(f=4,71$, $k=336,09), \quad \chi=3 \quad(f=6,92, \quad k=262,21), \quad \chi=4 \quad(f=9,13$, $k=204,56)$, y $\chi=5(f=11,34, k=159,59) ; b)$ la ecuación de Kastening-Holleck: $\chi=1$ ( $\mathrm{f}=2,50, k=430,795), \chi=2$ ( $\mathrm{f}=4,05$, $k=172,65), \quad \chi=3 \quad(f=4,93, \quad k=98,30), \quad \chi=4 \quad(f=5,51$, $k=65,74), y \chi=5(f=5,93, k=48,21)$.

derivative of the Damaskin-Parsons equation, apart from the term: $f$ (see Table I).

From the preceding discussion it is concluded that the Frumkin equation best describes the adsorption of BTA compound on copper electrode surfaces in the presence of $0.001,0.005$ and $0.01 \mathrm{M}$ concentrations of $\mathrm{H}_{2} \mathrm{SO}_{4}$ acid, and the slope, $\frac{\mathrm{d} \log (\mathrm{c})}{\mathrm{d} \theta}$, is a good parameter for distinguishing between the different isotherms tested. The discussion is now centred on results using the Frumkin isotherm. 
The isotherm slope. A criterion for studying the adsorption mechanism of benzotriazole on copper in sulphuric acid D.M. BASTIDAS, P.P. GÓMEZ AND E. CANO

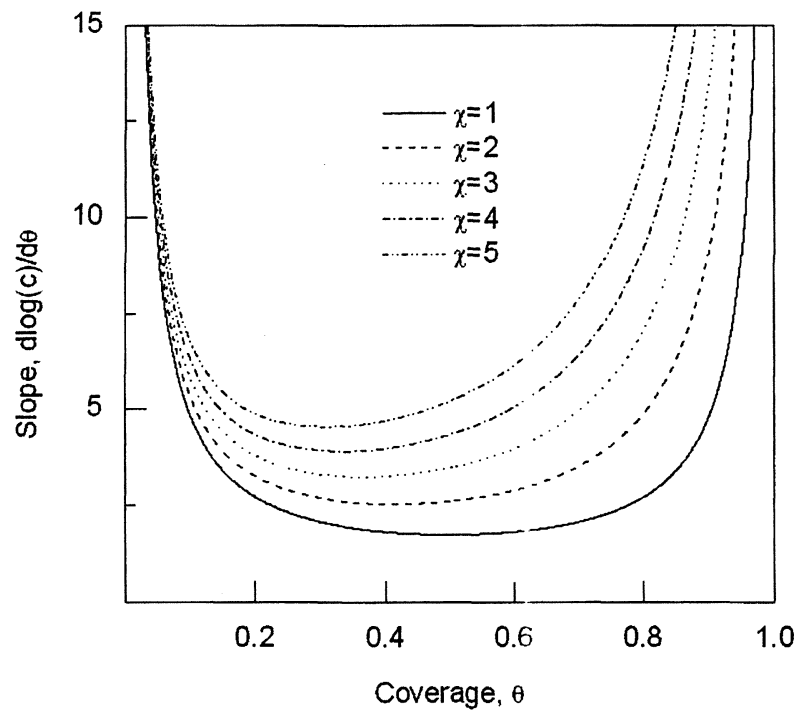

Figure 5. Slope versus coverage for $f=0$ and different values of $\chi$ using the Damaskin-Parsons equation.

Figura 5. Pendiente frente a recubrimiento para $\mathrm{f}=0$ y diferentes valores de $\chi$ utilizando la ecuación de DamaskinParsons.

Figure 6 shows $\theta$ versus BTA concentration for copper immersed in $0.001,0.005$ and $0.01 \mathrm{M}$ $\mathrm{H}_{2} \mathrm{SO}_{4}$ acid solutions and from 298 to $328 \mathrm{~K}$ using the Frumkin equation. This figure also shows the simulated data using the Frumkin equation. All the curves in figure 6 show an $S$ shape, as is predicted by the Frumkin equation, defining three regions on the isotherm plot: (i) at low BTA concentrations an increase in the BTA concentration does not produce an increase in $\theta$; (ii) at intermediate BTA concentrations a small increase in the BTA concentration causes a high $\theta$ (a linear dependence of $\theta$ versus $\log (\mathrm{c})$ ); and (iii) at high BTA concentrations $\theta$ is independent of the BTA concentration. It should be noted that no pitting corrosion was observed on the copper surface after experimentation in the presence and absence of BTA.

Table II lists the $f, \Delta \mathrm{G}_{\text {ads }}^{0}$ and $k$ parameters from figure 6 . The value of $f$ is different from zero and consequently is another proof that the adsorption mechanism cannot be related with the Langmuir equation model. The $f$ parameter values are positive, indicating a weak attraction between the adsorbed molecules. A positive value of $f$ has been associated with a vertical orientation of the inhibitor molecule on an electrode surface ${ }^{[34]}$. The negative value of the $\Delta G_{\text {ads }}^{0}$ parameter lies above $27.2 \mathrm{~kJ} / \mathrm{mol}$ and indicates that the reaction proceeds spontaneously for BTA compound and is accompanied by highly efficient adsorption.

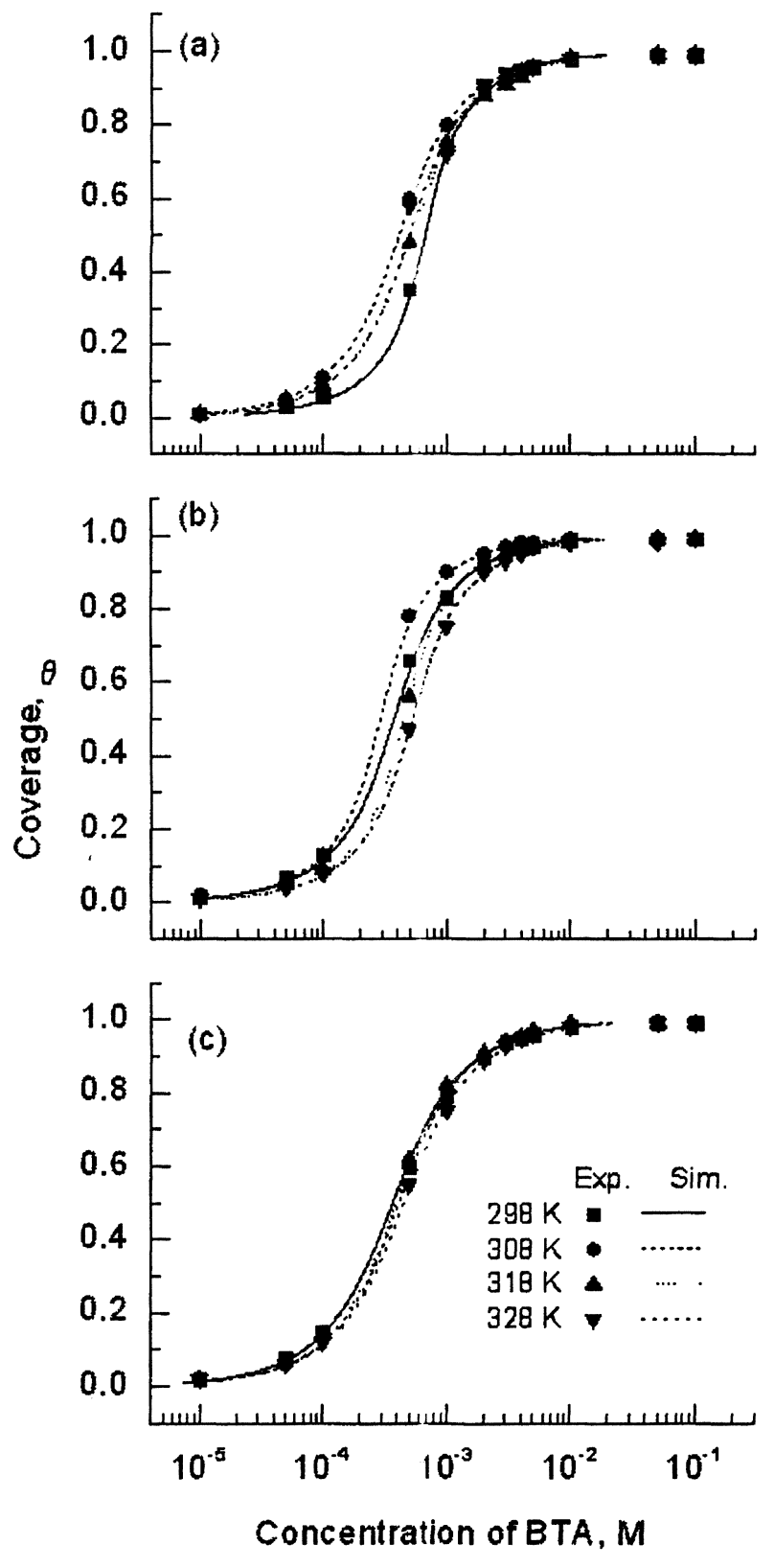

Figure 6. Coverage versus BTA concentration for copper in: (a) 0.001 , (b) 0.005 , and (c) $0.01 \mathrm{M} \mathrm{H}_{2} \mathrm{SO}_{4}$ acid solution using the Frumkin equation.

Figura 6. Recubrimiento frente a concentración de BTA para el cobre en distintas concentraciones de ácido $\mathrm{H}_{2} \mathrm{SO}_{4}$ : (a) 0,001 , (b) 0,005, y (c) 0,01 M utilizando la ecuación de Frumkin.

Finally, in order to calculate the optimal orientation of BTA for adsorption on the copper electrode surface, the projected molecular area of the BTA was calculated using molecular models $^{[35 \text { y 36] }}$. Figure 7 shows a schematic front view of the BTA inhibitor in a vertically orientation (left) and a horizontal orientation (right). The area occupied by vertically-oriented adsorbed BTA molecule is $\sim 20 \AA^{2}$ (the projected 
Table II. Thermodynamic data for copper in $\mathrm{H}_{2} \mathrm{SO}_{4}$ acid in the presence of BTA using the Frumkin equation

Tabla II. Datos termodinámicos del cobre en ácido $\mathrm{H}_{2} \mathrm{SO}_{4}$ en presencia de BTA utilizando la ecuación de Frumkin

\begin{tabular}{|c|c|c|c|c|}
\hline & Temperature, $\mathrm{K}$ & $f$ & $\Delta \mathrm{G}_{\mathrm{ads},}^{0} \mathrm{~kJ} / \mathrm{mol}$ & k \\
\hline \multirow{4}{*}{$0.001 \mathrm{M}$} & 298 & 2.50 & -27.4 & 431 \\
\hline & 308 & 1.71 & -28.3 & 1038 \\
\hline & 318 & 1.66 & -29.0 & 838 \\
\hline & 328 & 1.83 & -29.2 & 807 \\
\hline \multirow{4}{*}{$0.005 \mathrm{M}$} & 298 & 1.85 & -27.2 & 1057 \\
\hline & 308 & 2.28 & -28.2 & 1105 \\
\hline & 318 & 2.33 & -28.0 & 725 \\
\hline & 328 & 2.02 & -28.8 & 687 \\
\hline \multirow{4}{*}{$0.01 \mathrm{M}$} & 298 & 1.39 & -27.8 & 1361 \\
\hline & 308 & 1.57 & -28.2 & 1110 \\
\hline & 318 & 1.59 & -29.3 & 1150 \\
\hline & 328 & 1.43 & -30.0 & 1079 \\
\hline
\end{tabular}
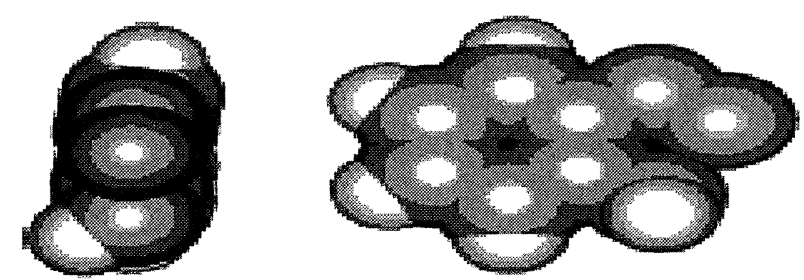

Figure 7. Front view of BTA molecule in vertical orientation (left) and in horizontal orientation (right).

Figura 7. La molécula de BTA vista de frente en orientación vertical (izquierda) y en orientación horizontal (derecha).

area of a rectangle surrounding the molecule), as compared with $\sim 38 \AA^{2}$ for the horizontal orientation of BTA. These values were obtained after configuration calculations using the Weblab ViewerPro Program from Molecular Simulation Inc and the value of Van der Waal's atomic radii ${ }^{[37]}$. The area occupied by a vertically-adsorbed water molecule is in the range form 8 to $12 \AA^{2[36]}$. These results may be interpreted as a vertical orientation of BTA on the copper surface, where each BTA molecule displaces several water molecules on the copper surface. The apparent contradiction of the displacement of more than one water molecule when using the Frumquin equation has been attributed to the fact that one adsorption site on the copper surface is occupied by a group of associated water molecules ${ }^{[38]}$.

\section{CONCLUSIONS}

The slope of the isotherm plot is a good approach for discerning between the interaction ( $f$ parameter) and substitutional ( $\chi$ parameter) adsorption mechanisms. The numerical method performed using the objective function $(F)$ is a good approach for corroborating the above ( $f$ and $\chi$ ) mechanisms.

An increase in inhibitor coverage was observed as a function of increasing BTA concentration. BTA compound was adsorbed on the copper surface according to a Frumkin isotherm model.

The projected molecular surface area method is a good approach for correlating the effectiveness of film-forming BTA corrosion inhibitor on copper in sulphuric acid solution with the BTA concentration.

\section{REFERENCES}

[1] J.R. DAVIS, ASM Special Handbook Copper and Copper Alloys. ASM International, OH, (2001), pp. 153 y 320.

[2] J.M. Bastidas y E. Otero, Mater. Corros. 47 (1996) 333 337.

[3] L.A. Godínez, Y. Meas, R. Ortega-Borges Y A. Corona, Rev. Metal. Madrid 39 (2003) 140-158.

[4] E. Bolaños-Rodríguez, S. Gil-Fundora, W. FranciscoMartín y J. Álvarez-Álvarez, Rev. Metal. Madrid 38 (2002) 134-138.

[5] G.W. Poling, Corros. Sci. 10 (1970) 359-370.

[6] D. Tromans Y G. Li, Electrochem. Solid St. 5 (2002) B5B8.

[7] F. Mansfeld, E.P. SMith Y E.P. ParRy, Corrosion 27 (1971) 289-294.

[8] G. LewIS, Brit. Corros. J. 16 (1981) 169-171.

[9] I. Dugdale Y J.B. Cotton, Corros. Sci. 3 (1963) 69-74.

[10] D. Papapanayiotou, H. Deligianni Y R.C. Alkire, J. Electrochem. Soc. 145 (1998) 3016-3024.

[11] J.B. COTton Y I.R. SCHOlES, Brit. Corros. J. 2 (1967) 1-5.

[12] J. Rubin, I.G.R. Gutz, O. Sala Y W.J. Orville-Thomas, J. Mol. Struct. 100 (1983) 571-583.

[13] D. Tromans Y R.H. Sun, J. Electrochem. Soc. 138 (1991) 3235-3244.

[14] M.R. Vogt, W. Polewska, O.M. Magnussen Y R.J. BEHM, J. Electrochem. Soc. 144 (1997) L113-L116.

[15] B.S. Fang, C.G. Olson Y D.W. Lynch, Surf. Sci. 176 (1986) 476-482.

[16] C. Tömkvist, D. Thierry, J. Bergman, B. Liedberg Y C. LEYGRAF, J. Electrochem. Soc. 136 (1989) 58-64.

[17] ASTM B-224 standard: Low Phosphorus Deoxidized Copper.

[18] ASTM G-1 standard: Practice for Preparing, Cleaning, and Evaluating Corrosion Tests Specimens. 
The isotherm slope. A criterion for studying the adsorption mechanism of benzotriazole on copper in sulphuric acid

D.M. BASTIDAS, P.P. GÓMEZ AND E. CANO

[19] E. Anzola, R. Malavé, V. Barrios, D. Villarroel, A. Tiso Y M. PARra, Rev. Metal. Madrid Vol. Extr. (2003) 157-161.

[20] I. Langmuir, J. Am. Chem. Soc. 40 (1918) 1361-1403.

[21] M.I. TEMKIN, Zh. Fiz. Khim. 15 (1941) 296-305

[22] A.N. Frumkin, Z. Phys. Chem. 116 (1925) 466-484.

[23] M. VOLMER, Z. Phys. Chem. 115 (1925) 253-261.

[24] T.L. Hill, J. Chem. Phys. 20 (1952) 141-144.

[25] J.H. DE BOER, The Dynamical Character of Adsorption, Oxford University Press, Oxford, (1953).

[26] E. Helfand, H.L. Frisch Y J.L. Lebowitz, J. Chem. Phys. 34 (1961) 1037-1045.

[27] R. PARsons, J. Electroanal. Chem. 8 (1964) 93-98.

[28] B.B. Damaskin, O.A. Petril Y V.V. Batrakov, Adsorption of Organic Compounds on Electrodes, Plenum Press, New York, (1971), pp. 86, 94 y 247.

[29] B. Kastening Y L. Holleck, Talanta 12 (1965) 1259 1288.
[30] J.O'M. BOCKRIS Y D.A.J. SwINKELS, J. Electrochem. Soc. 111 (1964) 736-743.

[31] J.R. MacDonald Y J.A. Garber, J. Electrochem. Soc. 124 (1977) 1022-1029.

[32] J.R. MacDonald Y L.D. PotTer JR, Solid State Ionics 23 (1987) 61-79.

[33] J.M. Bastidas, J.L. Polo, C.L. Torres Y E. Cano, Corros. Sci. 43 (2001) 269-281.

[34] J.J. Damborenea, J.M. Bastidas Y A.J. Vazquez, Electrochim. Acta 42 (1997) 455-459.

[35] J.M. Bastidas, J.L. Polo, E. Cano Y C.L. Torres, J. Mater. Sci. 35 (2000) 2637-2642.

[36] J.M. Bastidas, J.L. Polo Y E. Cano, J. Appl. Electrochem. 30 (2000) 1173-1177.

[37] A.L. LEARCH, Molecular Modeling. Principles and Applications, Prentice Hall, Harlow, (2001), p. 566.

[38] B.B. DAmaskin Y G.A. Tedoradze, Electrochim. Acta 10 (1965) 529-535. 